\title{
Analisis Perbandingan Excess Return Jakarta Islamic Index dan Indeks Harga Saham Gabungan
}

\section{A Comparative Analysis of Jakarta Islamic Index's and Indonesia Composite Index's Excess Return}

\author{
Galishia Putry $^{1}$, Iman Sugema ${ }^{2} \&$ Deni Lubis ${ }^{3}$ \\ ${ }^{1}$ Fakultas Ekonomi dan Manajemen IPB, Jl. Raya Darmaga Kampus IPB Darmaga, Bogor, Email : \\ gals.shia@gmail.com \\ ${ }^{2}$ Dosen Fakultas Ekonomi dan Manajemin IPB, Jl. Raya Darmaga Kampus IPB Darmaga, Bogor, \\ Email : isugema@gmail.com \\ ${ }^{2}$ Dosen Fakultas Ekonomi dan Manajemin IPB, Jl. Raya Darmaga Kampus IPB Darmaga, Bogor, \\ Email :denilubis@gmail.com
}

\begin{abstract}
Indonesia Stock Exchange statistics show that Islamic stock trading reached a value of around 59 trillion rupiahs. The excalation index of JII (Jakarta Islamic Index) is not follow by an increase in market capitalization of stocks listed on the JII. This is the question for investor who want to know how it compares to the performance of Jakarta Composite Index (JCI). This study analyzes the excess return that represents the return expected by an investor after investing in certain assets using descriptive analysis and Ordinary least square (OLS) regression of Capital Asset Pricing Model (CAPM). The descriptive analysis showed that in the same risk-free rate, investors who invest in stocks listed in JII can expect a higher return than the return JCI, while regression analysis shows investors do not expect the JII's excess return to be different from JCI's. This suggests that the selection criteria used by Bapepam LK (now OJK) and Indonesia Stock exchange does not affect the performance of return JII.
\end{abstract}

Keywords: CAPM, excess return, IHSG, JII, Rasio Sharpe

\begin{abstract}
Abstrak. Data statistik Bursa Efek Indonesia menunjukan bahwa perdagangan saham syariah mencapai nilai sekitar 59 triliun rupiah. Indeks JII (Jakarta Islamic Index) yang terus meningkat tidak diikuti oleh peningkatan kapitalisasi pasar saham-saham yang terdaftar pada JII. Hal ini jadi pertanyaan bagi para investor yang ingin mengetahui bagaimana perbandingan kinerja indeks JII dan IHSG (Indeks Harga Saham Gabungan). Penelitian ini menganalisis excess return yang merepresentasikan return yang diharapkan oleh seorang investor setelah menanamkan modal pada aset tertentu yang dengan analisis deskriptif dan regresi Ordinary least Square (OLS) pada model Capital Asset Pricing Model (CAPM). Hasil analisis deskriptif menunjukkan bahwa pada tingkat bebas risiko yang sama, investor yang menanamkan modal pada saham-saham yang terdaftar dalam JII dapat mengekspetasi return yang lebih tinggi dibandingkan return IHSG, sementara hasil regresi OLS menunjukkan bahwa investor pada JII tidak mengharapkan excess return yang berbeda dari IHSG. Hal ini menunjukkan bahwa kriteria seleksi yang digunakan oleh BAPEPAM LK (sekarang OJK) dan BEI tidak mempengaruhi performa return JII.
\end{abstract}

Kata kunci: CAPM, excess return, IHSG, JII, OLS 


\section{Pendahuluan}

Penerbitan Reksa Dana Syariah oleh PT. Danareksa Investment Management pada 3 Juli 1997 mengawali sejarah pasar modal syariah di Indonesia. Achsien (2000) menyebutkan bahwa pengembang pertama indeks syariah dan equity fund seperti reksa dana adalah Amerika Serikat, setelah The Amana Fund diluncurkan oleh The North American Islamic Trust sebagai equity fund pertama di dunia pada tahun 1986.

Keberadaan reksa dana syariah ini muncul sebagai jawaban atas kekhawatiran para investor beragama Islam mengenai bunga, spekulasi, dan ketidakjelasan pada investasi di reksa dana (Forte dan Miglietta 2007). Hal ini tertera pada QS. Al-Baqarah [2]: 275 yang mengharamkan riba atau bunga. Tiga tahun semenjak kemunculan Reksa Dana Syariah pertama di Indonesia, pada tanggal yang sama, Jakarta Islamic Index (JII) pertama kali diluncurkan oleh Bursa Efek Indonesia (BEI) bekerjasama dengan PT. Danareksa Investment Management. Sampai Februari 2014, data statistik BEI menunjukkan bahwa perdagangan saham syariah mencapai nilai sekitar 68 milyar rupiah.

Soemitra (2009) menyebutkan bahwa JII menjadi tolak ukur kinerja pasar modal syariah di Indonesia. Sebagai satu-satunya indeks syariah di Indonesia, JII mengacu pada satusatunya indeks saham yang merangkum seluruh aktivitas pasar modal di Indonesia yaitu Indeks Harga Saham Gabungan (IHSG) atau Jakarta Composite Index (JCI). Hal ini menjadi solusi bagi para investor yang ingin menanamkan modalnya pada saham-saham dari perusahaan yang terjamin kehalalan aktivitasnya.

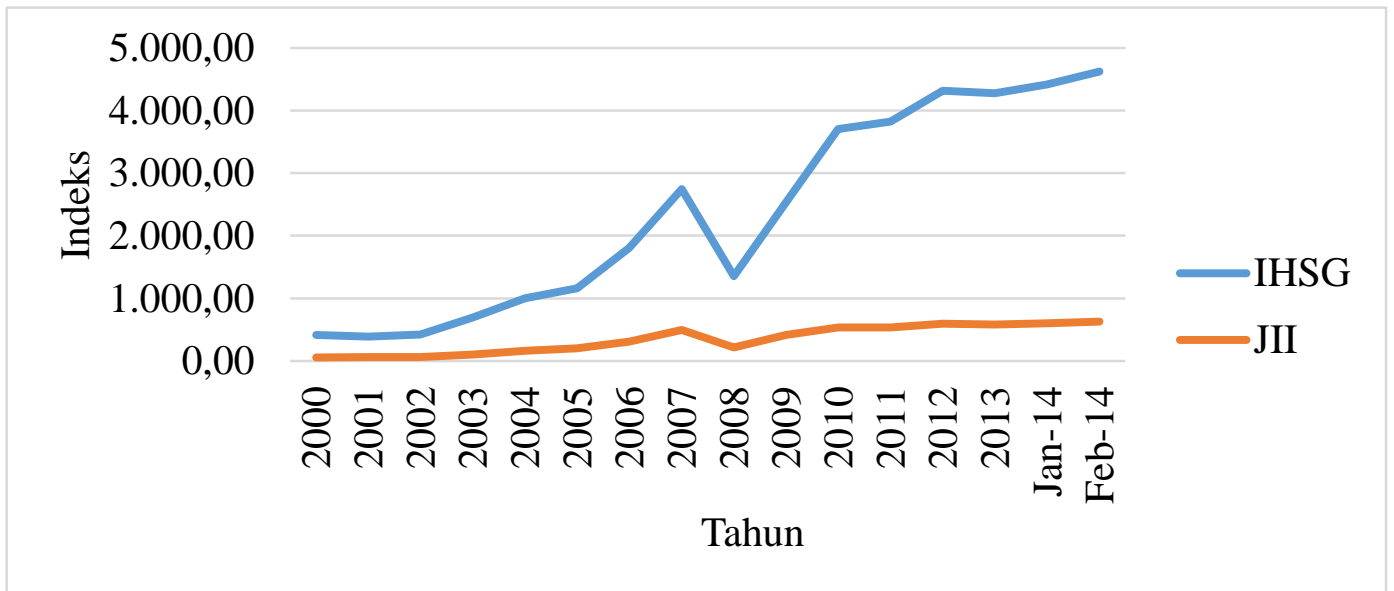

Sumber: Otoritas Jasa Keuangan, 2014

\section{Gambar 1 Grafik Nilai Indeks IHSG dan JII Periode 2000 - Februari 2014}

Berdasarkan Gambar 1, baik IHSG maupun JII mengalami kenaikan dari tahun 2000 hingga tahun 2007. Kemudian penurunan terjadi pada indeks IHSG dan JII pada tahun 2008. Amerika Serikat mengalami krisis hipotek subprime mortgage, dimana para pemilik rumah tidak mampu membayar cicilan kredit perumahan. Hal ini menunjukkan bahwa krisis di Amerika Serikat mempunyai pengaruh sampai ke Indonesia melalui mekanisme transmisi pada beberapa sektor seperti perdagangan, investasi, dan perbankan 
(Sani dan Wahyudi 2013). Selanjutnya, kedua indeks kembali meningkat pada tahun 2009 pasca krisis.

Berbeda halnya dengan perkembangan kapitalisasi pasar saham-saham yang terdapat pada JII. Walau secara nominal, jumlah kapitalisasi pasar Jakarta Islamic Index mengalami perkembangan yang serupa dengan indeks-nya dimana terjadi peningkatan dari tahun 2000 - Februari 2014, kecuali pada tahun 2008, persentase kapitalisasi saham-saham yang terdaftar pada JII terhadap keseluruhan saham yang terdapat pada Bursa Efek Indonesia mengalami pergerakan yang berbeda, seperti yang ditunjukkan pada Tabel 1 .

Tabel 1 Kapitalisasi Pasar pada BEI dan JII serta Persentase Kapitalisasi Pasar JII terhadap Keseluruhan Saham pada BEI

\begin{tabular}{crrc}
\hline Periode & \multicolumn{1}{l}{ BEI } & \multicolumn{1}{c}{ JII } & Persentase JII terhadap BEI (\%) \\
\hline 2000 & 259621.00 & 74268.92 & 28.61 \\
2001 & 239271.20 & 87731.59 & 36.67 \\
2002 & 268776.60 & 92070.49 & 34.26 \\
2003 & 460336.00 & 177781.89 & 38.62 \\
2004 & 679949.10 & 263863.34 & 38.81 \\
2005 & 801252.70 & 395649.84 & 49.38 \\
2006 & 1249074.50 & 620165.31 & 49.65 \\
2007 & 1988326.20 & 1105897.25 & 55.62 \\
2008 & 1076490.53 & 428525.74 & 39.81 \\
2009 & 2019375.13 & 937919.08 & 46.45 \\
2010 & 3247096.78 & 1134632.00 & 34.94 \\
2011 & 3537294.21 & 1414983.81 & 40.00 \\
2012 & 4126994.93 & 1671004.24 & 40.49 \\
2013 & 4219020.24 & 1672099.91 & 39.63 \\
Jan-14 & 4382396.37 & 1722863.16 & 39.31 \\
Feb-14 & 4576075.51 & 1791423.41 & 39.15 \\
\hline
\end{tabular}

Sumber: Otoritas Jasa Keuangan, 2014

Porsi kapitalisasi pasar saham-saham dalam daftar Jakarta Islamic Index pada Bursa Efek Indonesia meningkat dari tahun 2000 dan mencapai puncaknya pada tahun 2007 yakni sebesar 55.62\%. Tahun 2008 hingga 2012 terjadi fluktuasi pada persentase kapitalisasi pasar JII terhadap Bursa Efek Indonesia dan diikuti oleh penuruan dari tahun 2013 hingga Februari 2014. Indeks harga saham dan porsi kapitalisasi pasar JII yang perkembangannya bertolak belakang ini menjadi informasi penting bagi para investor. Beberapa penelitian juga mengkaji performa pasar modal syariah pada periode tersebut. Salah satunya adalah penelitian Majid dan Musnadi (2014) yang menjelaskan bahwa pasar modal syariah di Indonesia berperforma lebih baik dari pasar modal konvensional baik sebelum atau di saat krisis sedang terjadi. Beik dan Wardhana (2011) juga meneliti tentang pengaruh guncangan yang terjadi pada indeks-indeks konvensional dan syariah di Amerika Serikat dan Malaysia pada tahun 2006 - 2008 terhadap indeks-indeks di Indonesia yaitu IHSG dan JII. Hasil penelitian tersebut menunjukkan bahwa tidak ada hubungan jangka panjang antara pasar modal di Indonesia dengan di Amerika Serikat dan Malaysia. Selain itu, walau JII pada pendek secara signifikan terpengaruh oleh guncangan tersebut, hasil penelitian juga menyebutkan bahwa JII adalah yang yang paling kecil volatilitasnya dan lebih stabil. 
Analisis performa suatu indeks direpresentasikan pada elemen risiko dan return (Hosen, Rahman, dan Dutta 2013). Sharpe (1992) menjelaskan bahwa informasi mengenai return dapat membantu investor untuk menentukan efektifitas keseluruhan aset. Ukuran performa dari suatu indeks dapat ditentukan dengan membandingkan return yang diharapkan oleh seorang investor dengan return yang sebenarnya. Return ini disebut sebagai excess return atau abnormal return.

Langkah berikutnya dari seorang investor ialah menganalisis perbandingan antara asetasetnya dengan melihat bagaimana excess return yang didapat untuk kelebihan volatilitas yang ditahan oleh seorang investor untuk menanamkan modal pada aset yang lebih berisiko. Tingkat excess return ini dikalkulasikan dengan menggunakan Rasio Sharpe. Selain Rasio Sharpe, seorang investor juga dapat membandingkan risiko investasi dan return yang diharapkan antara JII dan IHSG dengan Capital Asset Pricing Model.

\section{Tinjauan Pustaka}

Terdapat tujuh jenis indeks di bursa efek Indonesia antara lain Indeks Individual, Indeks Harga Saham Sektoral, Indeks Harga Saham Gabungan (IHSG), Indeks LQ45, Indeks Papan Utama dan Papan pengembangan, Indeks KOMPAS 100, dan Indeks syariah. Indeks syariah terdiri dari ISSI (Indeks Saham Syariah Indonesia) dan JII (Jakarta Islamic Index). Kedua indeks ini mengacu pada Daftar Efek Syariah (DES) yang diterbitkan oleh OJK. Menurut website OJK, DES adalah kumpulan Efek yang tidak bertentangan dengan Prinsip-prinsip Syariah di Pasar Modal, yang ditetapkan oleh Bapepam-LK atau Pihak yang disetujui Bapepam-LK. DES merupakan panduan investasi bagi reksadana syariah dalam menempatkan dana kelolaannya serta juga dapat dipergunakan oleh investor yang mempunyai keinginan untuk berinvestasi pada profolio syariah.

Salah satu efek syariah dari DES adalah saham syariah. Pada prinsipnya, berdasarkan praktik yang berlaku di dunia internasional, terdapat dua kriteria utama untuk menentukan suatu saham layak disebut sebagai saham syariah atau tidak, yatu kriteria bisnis dan kriteria keuangan. Yang dimaksud kriteria bisnis adalah kriteria yang disusun berdasarkan jenis usaha dari setiap emiten. Kategori jenis usaha yang dijadikan indikator adalah berdasarkan kehalalan dari bisnis tersebut, baik halal karena zatnya (produknya) maupun prosesnya.

Berdasarkan arahan Dewan Syariah Nasional dan Peraturan Bapepam-LK no. IX.A.13 berikut adalah kriteria usaha yang bertentangan dengan prinsip-prinsip syariah:

1. Perjudian dan permainan yang tergolong judi

2. Perdagangan yang dilarang menurut syariah yaitu perdagangan yang tidak disertai dengan penyerahan barang/jasa atau penawaran/permintaan pasu.

3. Jasa keuangan ribawi, antara lain: bank berbasis bunga dan perusahaan pembiayaan berbasis bunga.

4. Jual bei risiko yang mengandung unsur ketidakpastian (gharar) dan/atau judi (maysir).

5. Memproduksi, mendistribusikan, memperdagangkan dan/atau menyediakan barang/jasa yang haram zatnya (hara li-dzaitihi), yang haram bukan karena zatnya (haramli-ghairihi) yang ditetapkan oleh DSN-MUI, dan/atau yang merusak moral dan bersifat mudarat.

6. Melakukan transaksi yang mengandung unsur suap.

Seleksi berdasarkan kriteria keuangan dilakukan untuk melihat komposisi dari pendapatan dan pembiayaan emiten yang berasal dari sumber non halal. Terdapat dua tingkat seleksi 
terhadap komposisi keuangan emiten. Pertama, seleksi berdasarkan komposisi sumber pembiayaan yang berasal dari sumber non halal atau pinjaman berbasis bunga dibandingkan modal perusahaan. Saat ini, persentase yang berlaku di pasar modal syariah Indonesia untuk komposisi hutang berbasis bunga terhadap modal perusahaan adalah tidak lebih besar dari $82 \%$.

Seleksi kedua adalah berdasarkan komposisi sumber pendapatan yang berasal dari non halal dibandingkan dengan total pendapatan termasuk pendapatan lain-lain. Persentase yang berlaku di Indonesia saat ini untuk perbandingan antara pendapatan non halal terhadap total pendapatan adalah tidak lebih dari $10 \%$

ISSI merupakan indeks saham yang mencerimnkan keseluruhan saham syariah yang tercatat di BEI dan mulai diluncurkan pada tanggal 12 Mei 2011. Konstituen ISSI adalah keseluruhan saham syariah tercatat di BEI dan terdaftar dalam Daftar Efek Syariah (DES). Konstituen ISSI di-review setiap enam bulan sekali dan dipublikasikan pada awal bulan berikutnya. Metode perhitungan indeks ISSI menggunakan rata-rata tertimbang dan pitalisasi pasar. Di sisi lain, JII merupakan indeks yang terdiri dari 30 saham mengakomodasi investasi syariah dalam Islam atau indeks yang berdasarkan syariah Islam (Soemitra 2009). Investasi dalam pasar modal memiliki risiko yang berbeda dengan investasi keuangan lainnya. Karena itu, investor perlu memahami apakah investasinya telah memberikan hasil yang lebih baik dari rata-rata pasar untuk itu diperlukan adanya tolak ukur berupa suatu indeks harga.

Soemitra (2009) menyatakan bahwa di samping sebagai tolak ukur, indeks syariah diperlukan untuk meningkatkan kepercayaan investor dan untuk mengembangkan reksa dana syariah. Indeks syariah diharapkan mampu memberikan transparansi akan laporan keuangan yang disumbangkan oleh para praktisi, pemenuhan ketentuan syariah sebagai hasil peran serta Dewan Syairah Nasional serta accountability dari pihak bursa efek yang melakukan monitoring.

Menurut website Bursa Efek Indonesia (BEI), saham syariah yang menjadi konstituen JII terdiri dari tiga puluh saham yang merupakan saham-saham syariah paling likuid dan memiliki kapitalisasi pasar yang besar seperti yang terdapat pada Lampiran 10. BEI melakukan review JII setiap enam bulan yang disesuaikan dengan periode penerbitan DES oleh Bapepam LK (sekarang OJK). Setelah dilakukan penyeleksian saham syariah oleh OJK yang dituangkan ke dalam Daftar Efek Syariah (DES), BEI melakukan proses seleksi lanjutan yang didasarkan kepada kinerja perdagangannya. Adapaun proses seleksi JII berdasarkan kinerja perdagangan saham syariah yang dilakukan oleh BEI adalah sebagai berikut:

1. Saham-saham yang dipilih adalah saham-saham syariah yang termasuk ke dalam DES yang diterbitkan oleh OJK.

2. Saham-saham terpilih kemudian diambil enam puluh saham berdasarkan urutan kapitalisasi terbesar selama satu tahun terakhir.

3. Dari enam puluh saham tersebut, kemudian dipilih tiga puluh saham berdasarkan tingkat lukuiditas yang urutan nilai transaksi terbesar di pasar regular selama satu tahun terakhir.

Ashraf (2013) menganalisis perbandingan excess return dari dua puluh sembilan indeks syariah di dunia seperti Dow Jones, S\&P, MSCI, dan FTSE dengan masing-masing indeks acuannya pada periode Desember 2000 sampai Mei 2012. Dengan menggunakan metode regresi linear persamaan tunggal dan jamak (Ordinary Least Square dan Seemingly Unrelated Regression), Ashraf menyimpulkan bahwa investor tidak mengharapkan return yang berbeda antara saham-saham yang terdaftar pada indeks- 
indeks syariah dan indeks-indeks konvensionalnya. Selain itu, kriteria penyeleksian pada indeks saham syariah memberikan pengukuran kinerja dan informasi yang lebih relevan mengenai skill manajemen dari manajer investasi.

Hussein (2004) menguji hipotesis bahwa kinerja FTSE indeks global Islam secara signifikan berbeda dari FTSE indeks All-world selama periode 1996-2003 yang dijadikan sebagai sampel dengan menggunakan analisis deskriptif. Perbandingan kinerja dari data mentah dan risiko yang telah disesuaikan (risk-adjusted) menunjukkan bahwa kinerja indeks Islam sama baiknya dengan indeks FTSE All-world selama keseluruhan periode. Ada bukti yang menunjukkan bahwa secara statistik indeks Islam menghasilkan return abnormal yang positif selama periode pasar yang naik, meskipun hal tersebut di bawah kinerja FTSE All-world pada periode pasar. Secara umum, hasil penelitian menunjukkan bahwa penerapan penyaringan berdasarkan syariah tidak memiliki dampak yang berlawanan (negatif) pada kinerja indeks Islam Global FTSE.

Penelitian Huda (2004) mengkaji faktor-faktor yang mempengaruhi beta saham pada kelompok JII dan LQ45 dengan menggunakan analisis deskriptif. Hasil penelitian antara lain menyatakan bahwa rata-rata beta saham kelompok JII berada pada nilai di bawah satu yang berarti mempunyai risiko di bawah risiko pasar, sebaliknya terjadi pada saham pada kelompok LQ45. Selain itu dalam penelitian ini juga terlihat bahwa lebih dari setengah emiten yang termasuk dalam kelompok JII memberikan return negatif sehingga secara rata-rata return kelompok JII memberikan nilai negatif.

\section{Metode Penelitian}

Jenis data yang digunakan dalam penelitian ini adalah data sekunder berupa data time series bulanan (monthly closing data) dari Januari 2005 hingga Februari 2014. Data-data yang digunakan pada penelitian ini adalah indeks harga saham Jakarta Islamic Index (JII), Indeks Harga Saham Gabungan (IHSG), tingkat kupon SBI berjangka 3 bulan untuk data bulan Januari 2005 hingga Oktober 2010 dan tingkat kupon Sertifikat Bank Indonesia (SBI) berjangka 9 bulan untuk data bulan November 2010 hingga Februari 2014. Perbedaan jangka waktu SBI ini dikarenakan pada pengumuman hasil lelang SBI, Bank Indonesia tidak mengumumkan adanya SBI berjangka waktu tiga bulan sejak bulan November 2010. Tingkat kupon SBI pada jangka waktu tersebut sama dengan nisbah bagi hasil Sertifikat Bank Indonesia Syariah (SBIS) sehingga data tersebut dapat digunakan untuk mencari excess return kedua indeks. Data diolah menggunakan Ms. Excel 2013 dan E-views 6.

Adapun tahap-tahap analisis yang dilakukan adalah sebagai berikut:

\section{a. Analisis Deskriptif}

Analisis deskriptif dilakukan dengan melihat mean, standar deviasi, dan tradeoff risiko dan return dari masing-masing excess return JII (Jakarta Islamic Index) dan IHSG (Indeks Harga Saham Gabungan). Trade-off ini disebut sebagai rasio Sharpe.

\section{b. Uji Stasionaritas Data}

Data time series pada umumnya bersifat stokastik atau memiliki tren. Tren melambangkan bahwa data tidak stasioner. Untuk dapat menjalankan regresi pada model, data harus bersifat stasioner atau tidak memiliki akar unit. Pengujian stasioneritas dilakukan dengan Uji Akar Unit yang dikemukakan oleh Dickey dan Fuller yaitu Uji Augrmented DickeyFuller. Data yang stasioner memiliki kecenderungan untuk mendekati nilai rata-rata-nya (Gujarati 2004). Jika terdapat akar unit pada level data, maka perlu dilakukan pembeda 
atau differencing sampai data tersebut tidak memiliki akar unit. Hipotesis nol menyatakan bahwa data memiliki akar unit dan untuk menolak hipotesis nol, hasil t-ADF harus lebih besar daripada nilai kritis McKinnon pada taraf nyata 5\% atau $p$-value $<5 \%$.

\section{c. Uji Normalitas Jarque-Bera}

Residual yang terdistribusi normal merupakan salah satu syarat atau asumsi yang harus dipenuhi pada regresi berganda dengan Ordinary Least Square. Normal atau tidaknya residual suatu data dapat ditunjukkan dengan Uji Jarque-Bera pada histogram-normality test. Hipotesis nol menyatakan bahwa residual data menyebar normal, sehingga untuk tidak dapat menolak hipotesis nol, p-value dari Jarque-Bera lebih besar dari taraf nyata 5\%. Gujarati (2006) menyatakan jika observasi berjumlah lebih dari 100, maka uji normalitas dapat diabaikan.

\section{d. Uji Autokorelasi LM}

Autokorelasi berakibat pada nilai statistik $t$ yang overestimate, sehingga tidak dapat disimpulkan apakah hasil regresi bersifat valid (Firdaus, 2011). Jika pada grafik plot residual terhadap waktu terdapat pola yang teratur maka terdapat indikasi adanya autokorelasi. Uji autokorelasi juga memperlihatkan Uji Durbin-Watson $(d)$. Hasil $d$ yang mendekati 0 menandakan adanya korelasi positif, $d$ yang mendekati 4 menandakan adanya korelasi negatif, sedangkan $d$ yang mendekati 2 menandakan tidak adanya autokorelasi. Selain dengan uji Durbin-Wason, autokorelasi juga dapat diidentifikasi keberadaanya dengan Uji Breusch-Godfrey Serial Corellation LM. Hipotesis nol pada Uji Autokorelasi LM adalah residual tidak memiliki autokorelasi. Untuk tidak dapat menolak hipotesis nol, maka $p$-value dari statistik F lebih besar dari taraf nyata 5\%.

\section{e. Uji Heteroskedastisitas White}

Heteroskedastisitas adalah ketidaksamaan varian dari residual untuk semua pengamatan pada model regresi. Terdapatnya heteroskedastisitas pada model regresi merupakann penyimpangn terhadap asumsi klasik heteroskedastisitas. Ada beberapa metode yang dapat digunakan untuk uji heteroskedastisitas, salah satunya adalah Uji White. Uji White meregresi residual kuadrat pada variable dependen ditambah kuadrat variable independen, kemudian ditambahkan lagi dengan perkalian dua variable independen. Hipotesisi nol pada Uji White adalah tidak terdapat heteroskedastisitas pada model. Untuk tidak menolak hipotesis nol, maka $p$-value dari residual kuadrat lebih besar dari taraf nyata 5\%.

\section{f. Regresi Ordinary Least Square Model CAPM (Capital Asset Pricing Model)}

Metode OLS paling sering digunakan (Gujarati 2006). Selain karena kemudahan, OLS juga memiliki beberapa sifat teoritis yang kokoh seperti yang diringkaskan di dalam teorema Gauss-Markov. Teorema Gauss-Markov menyatakan, "berdasarkan asumsiasumsi dari model regresi linear klasik, penaksir OLS memiiki varians yang terendah di antara penaksir-penaksir linear lainnya; dalam hal ini, penaksir OLS disebut sebagai penaksir tak bias linear terbaik (best liner unbiased estimators/BLUE).

Penelitian ini menggunakan model CAPM (Capital Asset Pricing Model) standar yang dapat dirumuskan sebagai berikut:

$$
R_{i t}=\alpha_{i}+\beta_{i j} R_{j t}+\varepsilon_{i t}
$$


$\mathrm{R}_{\mathrm{it}} \quad=$ excess return pada waktu $t$ untuk indeks JII

$\mathrm{R}_{\mathrm{jt}} \quad=$ excess return pada waktu $t$ untuk indeks IHSG

$\alpha \quad=$ konstanta alpha Jensen

$\beta_{\mathrm{ij}} \quad=$ risiko yang tidak bisa didiversifikasi

Rit dan Rjt menggambarkan excess return yang sudah dikurangi oleh return tingkat bebas risiko yang dalam kasus ini adalah tingkat kupon SBI. Konstanta alpha Jensen $i$ menggambarkan keadaan excess return indeks JII setelah disesuaikan dengan excess return indeks acuan IHSG atau intersep ketika excess return indeks berada pada posisi 0 . $\beta_{\mathrm{ij}}$ melambangkan bagaimana pergerakan excess return indeks JII terhadap perubahan pada excess return indeks acuan IHSG. Ketika $\beta_{\mathrm{ij}}>1$, maka excess return indeks JII relatif lebih agresif daripada excess return indeks acuan IHSG. Ketika $\beta_{\mathrm{ij}}<1$ atau $\beta_{\mathrm{ij}}=1$ maka risiko pada excess return indeks JII relatif lebih kecil atau bergerak sejalan dengan excess return indeks acuan IHSG.

Model CAPM di atas diestimasi dengan regresi Ordinary Least Square (OLS). Untuk mendapatkan model regresi yang terbaik, ada beberapa karakteristik yang harus dipenuhi yaitu hasil $\mathrm{R}^{2}$ yang tinggi, residual tidak memiliki autokorelasi, tidak ada heteroskedastisitas pada residual, dan residual tersebar secara normal atau residual bersifat acak (random). Dengan menggunakan Tes Autokorelasi-LM, ada atau tidaknya autokorelasi pada residual dapat diuji. Untuk menunjukkan adanya heteroskedastisitas, Uji Heteroskedastisitas White (1980) dilakukan terhadap residual. Sementara distribusi residual dilakukan dengan Uji Normalitas Jarque-Bera.

\section{Pembahasan}

Penelitian ini menganalisis pengaruh excess return Indeks Harga Saham Gabungan terhadap excess return Jakarta Islamic Index (JII). Hasil deskripsi didapatkan dari olahan data mentah yang terdapat pada Lampiran 1. Rata-rata excess return JII sebesar 0.0626185 dengan standar deviasi 0.0745329 , sedangkan rata-rata excess return IHSG adalah sebesar -0.0611657 dengan standar deviasi 0.0711913. Hal ini menunjukkan bahwa secara rata-rata excess return JII lebih kecil dari excess return IHSG.

Rata-rata Excess return yang negatif mengindikasikan bahwa tingkat return yang didapatkan oleh seorang investor baik pada JII dan IHSG lebih rendah daripada tingkat return yang didapat seorang investor dari investasi bebas risiko (SBI dan SBIS). Investor akan lebih tertarik untuk menanamkan kekayaannya dalam bentuk deposito. Menanamkan dana pada saham saat tingkat suku bunga SBI/SBIS tinggi akan menghilangkan kesempatan untuk memperoleh keuntungan yang lebih tinggi (Makaryanawati dan Ulum 2009). Hal ini sesuai dengan hasil penelitian yang dilakukan oleh Lenny dan Handoyo (2008) yang menyatakan bahwa IHSG dipengaruhi secara signifikan oleh harga minyak dunia dan tingkat suku bunga SBI pada taraf kepercayaan 95 persen.

Tabel 2 Rata-rata, standar deviasi, dan Rasio Sharpe JII dan IHSG

\begin{tabular}{llll}
\hline Index & $\begin{array}{l}\text { Mean Excess } \\
\text { Return }\end{array}$ & Standar Deviasi & Rasio Sharpe \\
\hline Jakarta Islamic Index & -0.0626185 & 0.0745329 & -0.8401458 \\
\hline Indeks Harga Saham Gabungan & -0.0611657 & 0.0711913 & -0.8590477
\end{tabular}

Sumber: olahan data pada Ms. Excel 
Hasil dari Rasio Sharpe kedua indeks tersebut menghasilkan angka yang negatif. Hal ini dapat disebabkan oleh dua hal yaitu terjadi penurunan pada harga indeks yang menyebabkan return menjadi negatif atau return kedua indeks lebih kecil dari tingkat bebas risiko yang dalam penelitian ini adalah tingkat kupon SBI, sehingga ketika return dikurangi tingkat kupon SBI hasilnya menjadi negatif (McLeod dan van Vuuren 2004).

Secara nominal, terlihat bahwa Rasio Sharpe JII lebih besar daripada Rasio Sharpe IHSG. Rasio Sharpe JII yang lebih besar dari IHSG menunjukkan bahwa pada tingkat risiko yang sama, seorang investor yang menanamkan modal pada saham-saham yang terdaftar dalam JII dapat mengekspetasi return yang lebih tinggi dibandingkan return IHSG. Hal ini dikarenakan saham-saham yang terdaftar dalam JII, setelah melalui kriteria baik kriteria bisnis dan kriteria keuangan, dilanjutkan dengan penyeleksian saham dengan kapitalisasi terbesar dan tingkat likuiditas terbaik. Hal ini menunjukkan bahwa sahamsaham di JII selain sudah sesuai dengan prinsip syariah, juga merupakan saham-saham terbaik. Amihud dan Mendelson (1986) dalam Xiao dan Kong (2012) menjelaskan bahwa aset dengan likuiditas rendah dan biaya dagang yang tinggi seringkali mempunyai dividen yang lebih tinggi.

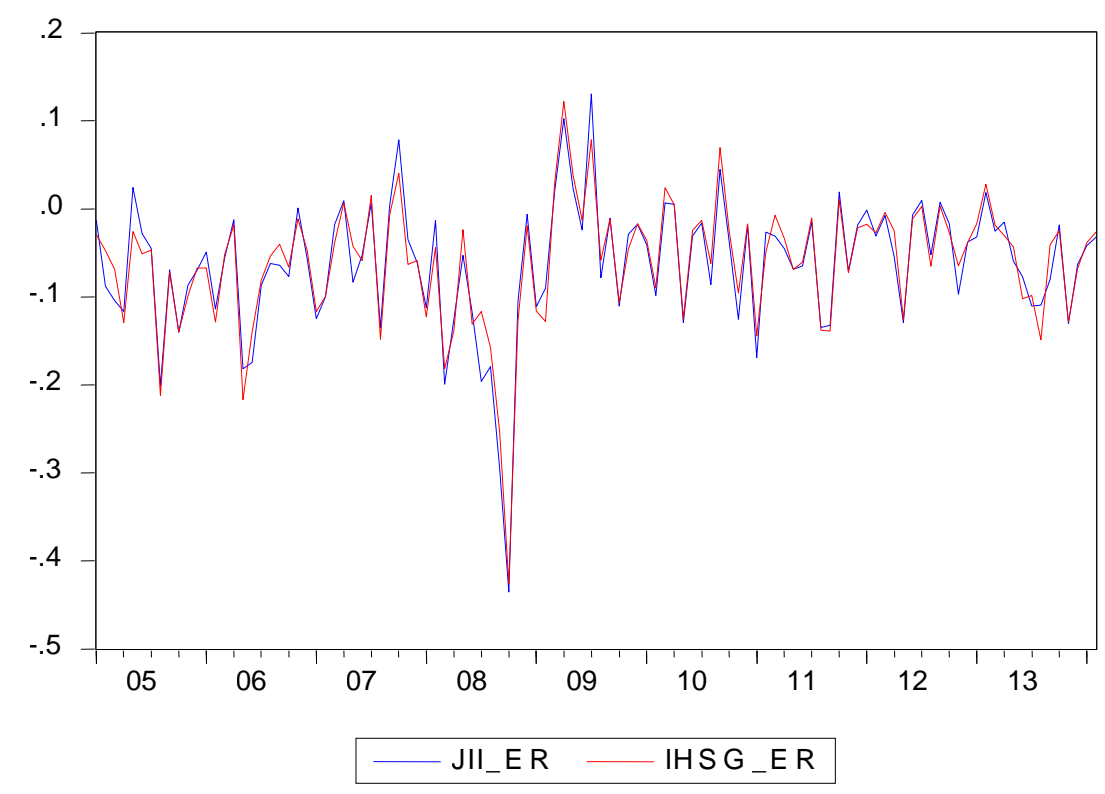


Sumber: olahan pada E-views

Gambar 3 Excess return indeks JII (JII_ER) dan IHSG (IHSG_ER) periode Januari 2005 s.d. Februari 2014

Hal yang penting untuk diamati dalam penelitian ini adalah menjawab pertanyaan mengenai excess return Indeks Harga Saham Gabungan (IHSG) mempengaruhi excess return Jakarta Islamic Indeks (JII). Gambar 2 menggambarkan fluktuasi excess return JII dan IHSG. Berdasarkan plot data bulanan excess return IHSG dan JII periode Januari 2005 - Februari 2014 terlihat bahwa data excess return berfluktuasi setiap bulannya. Periode sebelum krisis yaitu periode Januari 2005 hingga Mei 2008 terlihat baik excess return JII maupun IHSG cenderung stabil. Penurunan tajam terjadi pada periode Juni 2008 hingga Oktober 2008 di masa-masa krisis. Kedua indeks kembali meningkat sampai kepada excess return tertinggi pada Juni 2009. Pasca krisis yakni Juli 2009 hingga Februari 2014 menunjukkan pergerakkan yang fluktuatif seperti pada saat sebelum krisis. Berikut statistik deskriptif return indeks saham ditampilkan pada Tabel 3.

Tabel 3 Statistika Deskriptif Data Excess Return JII dan IHSG

\begin{tabular}{lllll}
\hline Indeks Saham & Skewness & Kurtosis & Jarque-Bera Test & Prob. \\
\hline JII & -1.3016 & 8.2231 & 156.0927 & 0.000000 \\
\hline IHSG & -1.3680 & 8.4466 & 170.2777 & 0.000000 \\
\hline
\end{tabular}

Sumber: olahan data pada E-views

Tabel 3 mengilustrasikan nilai Skewness dan Kurtosis dari kedua variabel seperti yang terdapat pada Lampiran 2. Skewness menunjukkan kemenjuluran yang merupakann ukuran kemiringan. Nilai Skewness yang kurang dari nol menunjukkan bahwa data memiliki distribusi yang miring ke kiri artinya data cenderung menumpuk pada nilai yang tinggi. Di sisi lain, Kurtosis memberikan informasi mengenai keruncingan dan digunakan untuk mengukut tingkat kepadatan sebaran. Keruncingan ini menggambarkan fluktuasi dan stabilitas pada masing-masing indeks. Semakin tinggi nilai Kurtosis semakin tingginya keruncingan yang mengindikasikan semakin tingginya fluktuasi indeks dan semakin tidak stabilnya indeks tersebut. Tabel 3 menunjukkan bahwa nilai Kurtosis IHSG lebih besar daripada nilai Kurtosis JII yang menandakan bahwa excess return IHSG lebih berfluktuasi daripada excess return JII atau JII lebih stabil daripada excess return IHSG.

Sebelum menganalisis hasil regresi dari model CAPM, dilakukan beberapa uji agar asumsi data OLS menjadi Best, Linear, Unbiased Estimator atau yang biasa disingkat BLUE (Firdaus 2011). Uji stasioneritas data dalam penelitian ini menggunakan uji akar unit atau Uji Augmented Dickey-Fuller dengan menggunakan taraf nyata 5\% untuk data excess return JII dan IHSG. Pengujian akar unit dilakukan pada level dengan memasukkan intersep. Panjang lag ditentukan berdasarkan kriteria informasi Schwarz. Pengujian akar unit dilakukan pada tingkat level. Hasil Uji Augmented Dickey-Fuller dapat dilihat pada Tabel 4.

Tabel 4 Hasil Uji Augmented Dickey-Fuller

\begin{tabular}{cccc}
\hline Variabel & $\begin{array}{c}\text { Nilai t-ADF pada } \\
\text { level } *\end{array}$ & $\begin{array}{c}\text { Nilai McKinnon pada } \\
\text { level }\end{array}$ & p-value \\
\hline Excess return JII & -7.472196 & -2.888157 & 0.0000 \\
\hline Excess return IHSG & -7.385432 & -2.888157 & 0.0000 \\
\hline
\end{tabular}


*taraf nyata $5 \%$

Sumber: olahan data pada E-views

Data excess return JII dan IHSG stasioner pada level dengan taraf nyata 5\% dengan hasil lebih lengkap yang terdapat pada Lampiran 3 dan 4 . Hal tersebut ditunjukkan oleh nilai absolut t-ADF yang lebih besar dari nilai kritis McKinnon pada taraf nyata 5\%. Hal tersebut mengindikasikan bahwa data penelitian ini terintegrasi dan tidak memiliki akar unit pada level. Oleh karena itu untuk menganalisis pengaruh excess return IHSG terhadap excess return JII dapat diestimasi dengan Ordinary Least Square (OLS).

Autokorelasi menggambarkan adanya pola yang teratur pada plot residual terhadap waktu. Asumsi dari model regresi yang terbaik adalah tidak adanya autokorelasi pada residual. Untuk menguji ada atau tidaknya autokorelasi pada sebuah regresi dilakukan Uji LM Autokorelasi Breusch-Godfrey. Hipotesis nol menyatakan bahwa tidak terdapat autokorelasi pada residual. Oleh karena itu, untuk mendapatkan model regresi terbaik, maka $p$-value untuk $\mathrm{R}^{2}$ pada hasil Uji Autokorelasi lebih besar dari taraf nyata 5\% agar hipotesis nol tidak ditolak. Berdasarkan hasil Uji Autokorelasi Breusch-Godfrey seperti yang ditunjukkan pada Lampiran $5, p$-value dari $\mathrm{R}^{2}$ adalah sebesar $15.22 \%$. P-value yang lebih besar dari taraf nyata 5\% menunjukkan hipotesis nol tidak ditolak dan mengindikasikan bahwa tidak ada autokorelasi pada residual, sehingga model memenuhi asumsi ini.

Asumsi model regresi terbaik selanjutnya adalah bahwa residualnya bersifat homoskedastis atau dapat dikatakan juga bahwa residual tidak bersifat heteroskedastis. Untuk memenuhi asumsi tersebut, maka Uji Heteroskedastisitas White dilakukan pada residual. Hipotesis nol menyatakan bahwa residual bersifat homoskedastis. P-value dari $\mathrm{R}^{2}$ hasil Uji Heteroskedastisitas White yang didapatkan hasilnya seperti pada Lampiran 6 adalah $77.60 \%$. P-value yang lebih besar dari taraf nyata $5 \%$ menyatakan bahwa hipotesis nol tidak dapat ditolak, sehingga residual bersifat homoskedastis sesuai dengan asumsi model regresi terbaik.

Model CAPM untuk excess return JII dan IHSG yang diestimasikan menggunakan regresi OLS memiliki koefisien determinasi $\left(\mathrm{R}^{2}\right)$ yang cukup tinggi yakni sebesar $92.58 \%$. Hal ini menyatakan bahwa data sudah menggambarkan model dengan baik. Signifikansi variabel dapat dilihat pada t-statistik dan F-statistik. Koefisien suatu variabel dapat dinyatakan signifikan jika $p$-value kurang dari 5\%. P-value untuk konstanta $(\alpha)$ adalah $69.43 \%$. Hal ini menunjukkan bahwa konstanta $(\alpha)$ tidak signifikan, karena $p$-value dari tstatistik $\alpha$ lebih dari 5\%. P-value untuk t-statistik dari excess return IHSG $(\beta)$ adalah $00.00 \%$. Hal ini menunjukkan bahwa koefisien dari excess return IHSG $(\beta)$ signifikan, karena $p$-value kurang dari 5\%. F-statistik mempunyai $p$-value sebesar 0.00 yang mengindikasikan bahwa F-statistik signifikan terhadap model karena $p$-value lebih kecil dari taraf nyata 5\%. F-statistik menggambarkan signifikansi dari gabungan $\alpha$ dan $\beta$ terhadap model.

Tabel 5 Hasil estimasi model CAPM dengan regresi OLS

Dependent Variable: JII_ER

Method: Least Squares

Date: 08/25/14 Time: 11:00

Sample: 2005M01 2014M02

Included observations: 110

Variable Coefficient Std. Error t-Statistic Prob. 


\begin{tabular}{lllll}
\hline \hline C & -0.001012 & 0.002569 & -0.394038 & 0.6943 \\
IHSG_ER & 1.007353 & 0.027440 & 36.71059 & 0.0000 \\
\hline \hline R-squared & 0.925807 & Mean dependent var & -0.062619 \\
Adjusted R-squared & 0.925120 & S.D. dependent var & 0.074533 \\
S.E. of regression & 0.020395 & Akaike info criterion & -4.929009 \\
Sum squared resid & 0.044925 & Schwarz criterion & -4.879910 \\
Log likelihood & 273.0955 & Hannan-Quinn criter. & -4.909094 \\
F-statistic & 1347.668 & Durbin-Watson stat & 1.987890 \\
Prob(F-statistic) & 0.000000 & & \\
\hline \hline
\end{tabular}

Sumber: olahan data pada E-views 6

Penelitian ini mengamati apakah JII tidak memiliki excess return yang berbeda dari indeks acuannya yaitu IHSG. Uji Koefisien Restriksi Wald dilakukan untuk menguji hipotesis tersebut. Jika hipotesis tersebut merupakan hipotesis nol, maka hipotesis nol dapat digambarkan sebagai $\alpha_{\mathrm{i}}$ tidak berbeda dari nol secara statistik dan $\beta_{\mathrm{ij}}$ sama dengan 1. Jika hipotesis nol tidak ditolak, maka kriteria yang digunakan JII menghasilkan excess return yang sama dengan indeks acuannya. Hasil Uji Koefisien Wald dapat dilihat pada Tabel 5.

Tabel 6 Hasil regresi OLS terhadap persamaan tunggal CAPM dan Spanning Test dengan Uji Koefisien Restriksi Wald

\begin{tabular}{cccccc}
\hline $\begin{array}{c}\text { Konstanta } \\
(\alpha)\end{array}$ & $\begin{array}{c}\text { Koefisien } \\
\text { IHSG }(\beta)\end{array}$ & $\begin{array}{c}\text { Koefisien } \\
\text { determinasi } \\
\left(\mathrm{R}^{2}\right)\end{array}$ & $\begin{array}{c}\text { Prob. } \mathrm{H}_{0}: \alpha \\
=0\end{array}$ & Prob. $\mathrm{H}_{0}: \beta=1$ & $\begin{array}{c}\text { Prob. } \mathrm{H}_{0}: \alpha=0 \text { \& } \\
\beta=1\end{array}$ \\
\hline-0.001012 & 1.007353 & 0.925807 & 0.6943 & 0.7892 & 0.7280 \\
\hline
\end{tabular}

Sumber: olahan data pada E-views 6

Tabel 5 menunjukkan hasil regresi OLS terhadap model persamaan tunggal CAPM. Hasil tersebut menunjukkan bahwa alpha bernilai negatif dan mendekati nol. Koefisien $\beta$ yang menunjukkan risiko sistematis signifikan pada taraf nyata $5 \%$ mengindikasikan bahwa excess return JII dapat dijelaskan secara relative terhadap IHSG. Hipotesis nol pada Spanning Test akan ditolak ketika p-value (prob) dari hasil Uji Wald lebih kecil dari taraf nyata $5 \%$. Hipotesis nol pertama menyatakan bahwa $\alpha$ sama dengan nol, hipotesis nol kedua menyatakan bahwa $\beta$ sama dengan 1, dan hipotesis nol ketiga merupakann gabungan dari hipotesis nol pertama dan kedua yakni $\alpha$ sama dengan nol dan $\beta$ sama dengan 1. Hasil Uji Wald yang ditunjukkan pada lampiran 7, 8, dan 9 membuktikan bahwa semua $p$-value untuk ketiga hipotesis nol lebih besar dari taraf nyata 5\%. Hal ini menunjukkan bahwa Uji Wald tidak dapat menolak ketiga hipotesis nol.

Hasil regresi OLS dari CAPM persamaan tunggal dan spanning test dengan Uji Koefisien Wald menunjukkan bahwa JII tidak menunjukkan performa yang berbeda dari IHSG yang merupakann indeks acuannya. Hal ini ditunjukkan oleh nilai alpha yang mendekati nol dan koefisien $\beta$ yang mendekati 1 dengan probablitas spanning test pada tiga hipotesis nol dimana alpha sama dengan 0 , koefisien $\beta$ sama dengan 1 dan gabungan kedua hipotesis yang ketiganya signifikan pada taraf nyata $5 \%$.

Hasil uji koefisien Wald tersebut mengindikasikan bahwa performa JII tidak berbeda dengan performa IHSG. Seorang investor yang menanamkan modal pada saham-saham yang terdaftar pada JII dapat mengekspetasi untuk mendapatkan excess return yang tidak berbeda dengan excess return saham-saham yang terdapat pada IHSG. Hal ini serupa 
dengan hasil penelitian Ashraf (2013) yang mengindikasikan bahwa kriteria seleksi yang dilakukan oleh OJK terhadap saham-saham pada IHSG yang masuk dalam daftar JII tidak memberikan pengaruh terhadap performa JII. Tidak berbedanya kinerja JII dan IHSG disebabkan oleh besarnya persentase kapitalisasi pasar JII di BEI. Saham-saham yang berada pada JII memiliki kapitalisasi pasar yang besar di bursa efek, hal ini mengakibatkan pasar yang cukup didominasi oleh saham-saham pada JII, sehingga performa keseluruhan saham-saham di BEI yang terlihat pada IHSG tidak menunjukkan perbedaan.

\section{Simpulan dan Saran}

Berdasarkan hasil penelitian yang telah dilakukan mengenai analisis perbandingan performa excess return Jakarta Islamic Index (JII) dan Indeks Harga Saham Gabungan (IHSG) periode Januari 2005 - Februari 2014 dengan analisis deskritptif, Rasio Sharpe, dan regresi persamaan tunggal Capital Asset Pricing Model (CAPM), diperoleh kesimpulan bahwa secara rata-rata, excess return JII lebih besar dari excess return IHSG dan Rasio Sharpe menunjukkan pada tingkat bebas risiko yang sama, seorang investor yang menanamkan modal pada saham-saham yang terdaftar dalam JII dapat mengekspetasi return yang lebih tinggi dibandingkan return IHSG. Kedua, melalui regresi CAPM pada excess return JII dan IHSG disimpulkan bahwa investor pada JII tidak mengharapkan excess return yang berbeda dari IHSG dan kriteria seleksi yang digunakan oleh BAPEPAM LK (sekarang OJK) dan BEI tidak mempengaruhi performa return JII.

Dari hasil penelitian di atas, rekomendasi kebijakan yang dapat diambil untuk dapat meningkatkan performa JII, emiten dari konsekuen saham yang tergabung dalam JII sebaiknya terus berupaya untuk memberikan inovasi-inovasi terhadap jenis investasi yang mereka tawarkan agar dapat menarik lebih banyak investor.

\section{Daftar Pustaka}

Achsien I. 2000. Investasi Syariah di Pasar Modal. Jakarta: Gramedia Pustaka Utama.

Ashraf D. 2013. Genesis of differential performance between Shari'ah compliant equity indices and conventional indices. 20th Annual Conference of the Multinational Finance Society [internet]; 2013 Juni 30- Juli 3; Al Khobar(SA): SSRN.

[BEI] Bursa Efek Indonesia. Januari 2005 - Februari 2014. IDX Monthly Statistics. [internet] Tersedia pada http://www.idx.co.id/id-id/beranda/publikasi/statistik.aspx

Fatwa dan landasan hukum pasar modal syariah. [internet] tersedia pada: http://www.idx.co.id/idid/beranda/produkdanlayanan/pasarsyariah/fatwadanlandasanhukum.aspx - Indeks saham syariah. [internet] tersedia pada http://www.idx.co.id/id-id/beranda/produkdanlayanan/pasarsyariah/indeks sahamsyariah.aspx

Beik IS, Wardhana W. 2011. The relationship between Jakarta Islamic Index and other selected markets: evidence from impulse response function. Majalah Ekonomi. 21(2): 100-109.

[BI] Bank Indonesia. Januari 2005 - Februari 2014. Pengumuman Hasil Lelang Sertifikat Bank Indonesia (SBI) dan Sertifikat Bank Indonesia Syariah (SBIS). [internet] Tersedia pada http://www.bi.go.id/id/moneter/lelang-sbi/Default.aspx

Departemen Agama RI. 2007. Al-qur'an dan Terjemahannya.

Ernst. Young. 2011. The Islamic Funds and Investment Report 2011, Achieving Growth in Challenging Times. 
Firdaus M. 2011. Aplikasi Ekonometrika untuk Data Panel dan Time Series. Bogor: IPB Press.

2011. Ekonometrika Suatu Pendekatan Aplikatif. Jakarta: Bumi Aksara.

Forte G, Miglietta F. 2007. Islamic mutual funds as faith-based funds in a socially responsible context [skripsi]. Milan(IT): Universitas Bocconi.

Gujarati DN. 2004. Basic Econometrics Fourth Edition. Boston: The McGrraw-Hill Compnies.

. 2006. Dasar-dasar Ekonometrika Edisi Ketiga Jilid 1. Jakarta: Erlangga.

Hosen MZ, Rahman MT, Dutta KD. 2013. Risk adjusted performance analysis of NBFIs in Dhaka Stock Exchange.

Huda N. 2004. Pasar modal syariah dan faktor-faktor yang memengaruhi beta saham kasus JII dan LQ45 [tesis]. Jakarta(ID): Universitass Indonesia.

, Nasution ME. 2008. Investasi pada Pasar Modal Syariah. Jakarta: Kencana.

Hussein K. 2005 Islamic Investment: Evidence from Dow Jones and FTSE Indices. Internatioanl Conference on Islamic Economics and Finance, Jakarta [internet]. [waktu dan tempat tidak diketahui]. Jakarta(ID).

Judge GG, Griffiths WE., Hill RC, L"utkepohl H, Lee TC. 1985. The Theory and Practice of Econometrics. 2nd ed. New York: Wiley.

Lenny b, Handoyo SE. 2008. Oengaruh harga minyak dunia, tingkat suku bunga Sertifikat Bank Indonesia dan Kurs Rp/USD terhadap Indeks Harga Saham Gabungan di Bursa Efek Indonesia [internet]. Jurnal Ekonomi. 13(3): 295-304.

Majid MSA, Musnadi S. 2014. A comparative analysis of diversification benefits between Islamic emerging and conventional largest world's markets during the 2007 global financial crisis. Banda Aceh (ID): Universitas Syiah Kuala.

Makaryanawati, Ulum M. 2009. Pengaruh tingkat suku bunga dan tingkat luiditas perusahaan terhadap risiko investasi saham yang terdafta pada Jakarta Islamic Index [internet]. Jurnal Ekonomi Bisnis. 14(1): 49-60.

McLeod W, van Vuuren G. 2004. Interpreting the Sharpe Ratio when excess returns are negative. Investment Analysis Journal.59: 15-20.

[OJK] Otoritas Jasa Keuangan. Pengantar daftar efek syariah [internet]. Tersedia pada: http://syariah.ojk.go.id/daftar_efek_syariah/index.html

Perold AF. 2004. The capital asset pricing model [internet]. Journal of Economic Perspectives. 18(3): 3-24.

Sani GA, Wahyudi I. 2013. Interdependence between Islamic capital market and money market: Evidence from Indonesia [internet]. The Ninth International Conference on Islamic Economics and Finance (ICIEF); 2013 September 9-10; Istanbul, Turkey. Doha (QA): QFIS, hlm 4-5; [diunduh 2014 Agustus 2014]. Tersedia pada: conference.qfis.edu.qa/app/media/7117

Schroder M. 2007. Is there a difference? The performance characteristics of SRI equity indices [internet]. Journal of Business Finance \& Accounting. 34(1 - 2): 331-348.

Sharpe WF. 1966. Mutual fund performance [internet]. Journal of Business. 39(1): 119138.

1992. Asset allocation: management style and performance measurement [internet]. Journal of Portfolio Management, Winter 1992. 18(2): 7-19. 49-59.

1994. The Sharpe ratio [internet]. Journal of Portfolio Management. 21(1):

Soemitra A. 2009. Bank \& Lembaga Keuangan Syariah. Jakarta: Kencana.

Xin-yuan X, Liu-liu K. 2012. An empirical study on the relationship between Turnover rate and stock returns in Chinese stock market [internet]. Advances in Information Technology and Management. 2(1): 239-245. 